\title{
EVALUATION OF TEACHERS' USE OF INSTRUCTIONAL MATERIALS FOR TEACHING FRENCH IN JUNIOR SECONDARY SCHOOLS
}

PRISCA COLETTE NKECHI EZENWA

(Received 18, December 2017; Revision Accepted 12, February 2018)

\begin{abstract}
The purpose of this survey was to evaluate the teachers' use of the instructional materials for teaching French as recommended in the junior secondary school curriculum for French. The population of the study consisted of the 20,384 junior secondary school students of French and their 34 teachers in the 23 junior secondary schools where French is studied in Owerri Education Zone 1 of Imo State. The sample comprised 360 students and 15 teachers of French selected through cluster random sampling. Two types of rating scale were used for the study, one for the students and the other for the teachers. The scales were researcher-made and each had 10 items that border on the instructional materials recommended in the junior secondary school curriculum for French. The instruments were validated using Crombach Coefficient Alpha. The students' and teachers' rating scales had reliability indices of 0.85 and 0.87 respectively. The data collected were analyzed using mean ratings, the percentage and $t-$ test at 0.05 level of significance. It was found that the instructional materials used by the teachers for teaching French were drawings and text books and that there is significant difference in the instructional materials for teaching French at the junior secondary school as specified in the junior secondary school curriculum for French and as used by the teachers of French. Part of the recommendations is that in the French language classroom, the teachers need to use instructional materials recommended in the French language curriculum so that while using the materials, the students can use French and so acquire the language skills for communicating in the language.
\end{abstract}

\section{INTRODUCTION}

In the National Policy on Education, the Federal Republic of Nigeria (2004:10) declares: "For smooth interaction with our neighbours, it is desirable for every Nigerian to speak French." It becomes clear, from this statement, that the primary aim of the inclusion of French in the Nigerian secondary school curriculum is to equip Nigerians with the skills for communication, especially with fellow Africans in the neighbouring French-speaking countries. Equipped with the competences for communication in French, the chances for employment for a Nigerian speaker of French abound both within and outside Nigeria in the areas of career development, national development, tourism, to mention but a few.
These and other benefits justify the teaching of French in Nigerian schools.

For the realization of this Government's desire for including French in the Nigerian school curriculum, there is need for effective teaching and learning of French in the schools. However, and sadly too, the teaching of French has been faced with a lot of challenges, manifested in the observed inability of the students to meaningfully communicate in French at the end of the junior secondary school. This inability could be traced to the teachers' inability to use the right methods for teaching French.

It is in response to the need to boost the teaching of French in Nigerian schools that the Federal Ministry of Education (2012) published the French language curriculum, Junior

Prisca Colette Nkechi Ezenwa, Department of Language Education, Imo State University, Owerri, Nigeria.

(C) 2018 Bachudo Science Co. Ltd. This work is licensed under Creative Commons Attribution 4.0 International license. 
Secondary Education Curriculum, French JSS 13 , for effective teaching of the language at the junior secondary school. Having designed the curriculum, there is need for its proper use, as guide for the teachers for effective teaching of French in schools. This means that the teacher uses his/her teaching strategies to bring it into classroom experience. The teacher's strategies are the teacher's plan of actions for implementing the curriculum and include the teacher's techniques for teaching.

A technique represents the particular strategies which the teacher adopts in teaching language. They include the activities which the teacher organizes in the classroom as well as the different instructional materials which the teacher uses to facilitate language learning. The Federal Ministry of Education (2012) realizes the importance of the teacher's strategies and specifies the techniques that teachers need to adopt in the teaching of French in Nigerian schools. This recommendation is built on the conviction that if teachers use the recommended techniques for teaching French, students will be able to learn and use the language for communication.

Part of the techniques recommended by the Federal Ministry of Education (2012) in the Junior Secondary Education Curriculum, French JSS 1-3 is the use of materials. These include images et posters (charts), photos (pictures), video (video), (p. 1/14), documents authentiques et autres documents (authentic materials and other materials (p. 1/2), extraits de journaux (newspaper extracts) (p. 6), television (television) (p. 17). Instructional materials are a wide range of objects and materials that the teacher can introduce into the learning situation, to facilitate learning by students. They are visual aids and include the objects such as maps, diagrams, pictures etc that the students can view and work with in the classroom; and they serve as visual stimuli for communicative interaction. They focus attention on a topic of communication, and direct questions and answers towards specific details.

Instructional materials are of great importance in language teaching and learning. Konomi (2015) observes that the use of visual aids such as pictures, posters, postcards, word calendars, realia, charts, graphic organizers, picture books, television, videos from iTunes, and computers can help young learners easily understand and realize the main points that they have learned in the classroom. Other instructional materials for teaching French include visuals like maps, diagrams, pictures and other instructional materials that can be drawn from the students' immediate environment as well as ICT resources like audio devices, video, television, telephone, the computer, the internet, word processor, e-mail, World Wide Web, multimedia and so on. Abebe and Davidson (2012) assert that visual instructional materials enhance language learning especially in the area of students' vocabulary learning. However, they observe that many teachers prefer to use textbooks only instead of supplementing the books with visual instructional materials.

The use of instructional materials is indispensable in the teaching of foreign language, especially when the materials are real objects used in the language community of the native speakers of the language. These authentic materials help to stimulate students' interest in the language. HATT (2000) adds that in foreign language classroom, authentic texts serve as partial substitute for the community of native speakers. These texts include newspaper and magazine articles, poems, manuals, receipts, telephone directives, videos, news bulletins and discussion programmes. All these can be used in a variety of ways.

Authentic materials are a type of real objects. They are those documents that were not primarily conceived for use in teaching but which could be very useful when effectively used in the language class. Many of the things that are found in the learners' environment can be used as instructional materials. These authentic materials can be printed labels from cans of beverages, packets of biscuits, soap, tins of beverages, medicine, restaurant menus, travel brochures, or cuts from newspapers, magazines, and other printed instructional materials used in real-life language activities. CESA Languages Abroad (2015) believes that through understanding and analyzing authentic documents such as newspaper and magazine articles, professional documents, forms and literature extracts reading skills are enhanced and written work is developed through a range of language activities designed to meet the students' communicative goals. It integrates the use of authentic materials into its methodology for teaching French to foreigners.

The instructional materials recommended in the French language curriculum include Information and Communication Technology (ICT) materials. The use of ICT is very effective for foreign language teaching and learning. 
These objects centre on the computer which plays a very significant role in language teaching especially the teaching of updated content as it allows access to information and knowledge. Other ICT materials include audio devices, video, DVD, television, telephone and the internet. These ICT instructional materials now abound in the environment of the Nigerian learners of French and could also function as authentic instructional materials.

Commendable as the junior secondary school French language curriculum provisions are, especially in recommending the instructional materials for teaching French in the schools, one wonders if the teachers use these materials for teaching French. There is, therefore, need for an evaluation of the teachers' use of the materials recommended in the French language curriculum.

\section{The Problem}

The status of the learning of French in Nigeria is a worrisome situation. It is observed that students are not able to express themselves meaningfully in French at the end of their secondary school and that teachers' strategies, mainly through conventional methods, have failed to equip learners with the expected language skills. These observations are a basic problem and run contrary to the aim of including French in the secondary school curriculum which is to make Nigerians speak French and communicate with it.

As the Federal Ministry of Education has responded to this problem by publishing the National curriculum for French, Junior Secondary Education Curriculum, French JSS 1-3, for use in teaching French in the junior secondary schools and recommending the teaching techniques that the teachers are expected to use in teaching French, one wonders whether the teachers of French use these techniques for teaching French and to what extent. Therefore, the problem of the study put in a question form is: To what extent do teachers of French use the instructional materials recommended in the Junior Secondary Education Curriculum, French JSS 1-3, for teaching French in the junior secondary schools? This study was carried out to answer the question.

\section{The Purpose}

The purpose of this study was to find out what instructional materials the teachers use for teaching French and the extent to which these teachers use the instructional materials recommended in the curriculum for teaching French. The following research questions guided the study:

1. What instructional materials do teachers use for teaching French?

2. To what extent do teachers of French use the instructional materials recommended in the French language curriculum?

The following null hypothesis was tested at 0.05 level of significance: There is no significant difference in the instructional materials used by the teachers of French and those recommended in the French language curriculum (P. < 0. 05).

\section{Research Procedure}

The survey sought to evaluate the extent of teachers' use of the instructional materials for teaching French as recommended in the curriculum for teaching French. The population of the study was made up of the 20,384 junior secondary school students of French and their 34 teachers in the 23 junior secondary schools where French is studied in Owerri Education Zone 1 of Imo State. The sample of the study included 360 junior secondary school students and 15 teachers of French selected through cluster random sampling. Out of the 5 Local Government Areas that make up Owerri Education Zone 1, 3 Local Government Areas were randomly selected, from each of which 3 schools were randomly selected. From each of the selected schools, 40 junior secondary school students were selected. All the teachers in the selected schools were used for the study. The students were included in the study because following the French language policy, it is the students who are to acquire the skills for communicating in the language and their involvement in the use of the instructional materials is very necessary. Therefore, the students need to be involved in the evaluation of the teachers' use of the instructional materials in the national curriculum for French.

Two structured rating scales were used in collecting data for the study, one for the students and the other for the teachers. The scales were researcher-made and each had 10 items that border on the instructional materials recommended in the curriculum for teaching French. The options in the scales include Always, Most times, Sometimes and Never. To ensure the face and content validity of the instruments, 
they were subjected to the scrutiny of 2 experts in Language Curriculum and one expert in Educational Measurement and Evaluation. Their comments and suggestions were put into consideration in restructuring the instruments. For the reliability of the instruments, 30 copies of the students' rating scale and 5 copies of the teachers' rating scale were administered to 30 students and 5 teachers respectively outside the research area. The administration of the instruments was repeated after 2 weeks. The data from the tests were subjected to analysis by Crombach Coefficient Alpha. Reliability indices of 0.85 and 0.87 were obtained for the students' and teachers' rating scales respectively. The researcher personally administered the instruments face-to-face to the respondents. She explained the rating scales to the respondents, especially the students before they responded to the rating scales. She waited for the copies of the rating scales to be filled in before she collected them back. As expected, all the copies sent out were well filled in and collected back by the researcher.

\section{Data Analysis and Results}

The data collected from the study were subjected to statistical analysis. The data were weighted in such a way that Always had 4 points, Most times had 3 points, Sometimes had 2 points and Never had 1 point. The research questions were answered in mean ratings and percentage. A mean score of 2.5 was considered as the acceptable level of teachers' use of the instructional materials in the curriculum for teaching French while a percentage of $55 \%$ was the accepted level of teachers' extent of use of the instructional materials in the national curriculum for French. The hypothesis was tested with t-test at 0.05 level of significance.

The results of the study are presented in
tables
1 ,
and
3.

Table 1: Students' responses to the rating scale. Number of Students $=360$

\begin{tabular}{|l|l|l|l|}
\hline S/N & ITEM & TOTAL SCORE & MEAN SCORE \\
\hline 1 & Charts & 625 & 1.7 \\
\hline 2 & Pictures & 622 & 1.7 \\
\hline 3 & Authentic materials & 639 & 1.8 \\
\hline 4 & Television & 474 & 1.3 \\
\hline 5 & Audio players & 448 & 1.2 \\
\hline 6 & Video & 468 & 1.3 \\
\hline 7 & Drawings & 1109 & 3.1 \\
\hline 8 & Textbooks & 1187 & 3.3 \\
\hline 9 & Story books & 642 & 1.8 \\
\hline 10 & Newspaper extracts & 494 & 1.4 \\
\hline
\end{tabular}

Table 2: Teachers' responses to the rating scale. Number of Teachers $=15$

\begin{tabular}{|l|l|l|l|}
\hline S/N & ITEM & TOTAL SCORE & MEAN SCORE \\
\hline 1 & Charts & 35 & 2.3 \\
\hline 2 & Pictures & 35 & 2.3 \\
\hline 3 & Authentic materials & 42 & 2.8 \\
\hline 4 & Television & 30 & 2.0 \\
\hline 5 & Audio players & 25 & 1.7 \\
\hline 6 & Video & 31 & 2.1 \\
\hline 7 & Drawings & 46 & 3.1 \\
\hline 8 & Textbooks & 55 & 3.7 \\
\hline 9 & Story books & 49 & 3.3 \\
\hline 10 & Newspaper extracts & 33 & 2.2 \\
\hline
\end{tabular}


Research Question 1: What instructional materials do the teachers use for teaching French?

From the students' responses, the instructional materials used by the teachers for teaching French include drawings (mean score of 3.1) and textbooks (mean score of 3.3) while from the teachers' responses, the instructional materials used by the teachers for teaching French include authentic materials (mean score of 2.8), drawings (mean score of 3.1) textbooks (mean score of 3.7 ) and story books (mean score of 3.3).

Therefore, (based on the students' and teachers' responses), the instructional materials used by the teachers for teaching French include drawings and text books.

Research Question 2: To what extent do the teachers of French use the instructional materials recommended in the French language curriculum?

From the students' responses for teaching French, the teachers use 2 out of the 10 instructional materials in the curriculum. This represents $20 \%$ in the extent of teachers' use of the instructional materials recommended in the curriculum for teaching French. From the teachers' responses, for teaching French the teachers use 4 out of the 10 instructional materials in the curriculum. This represents $40 \%$ in the extent of teachers' use of the instructional materials recommended in the curriculum for teaching French.

Therefore, (based on the students' and teachers' responses), the teachers use 2 out of the 10 instructional materials in the curriculum. The teachers' use of instructional materials for teaching French represents $20 \%$ of the instructional materials recommended in the curriculum for teaching French.

The Null Hypothesis: There is no significant difference in the instructional materials used by the teachers of French and those recommended in the curriculum for teaching French (P. < 0. 05). The test of Hypothesis 1 is presented in table 3.

Table 3: t-test Analysis of the Null Hypothesis

\begin{tabular}{|l|l|l|l|l|l|l|}
\hline & $\mathbf{N}$ & $\overline{\mathbf{X}}$ & $\mathbf{S D}$ & $\mathbf{t}_{\text {tab }}$ & $\mathbf{t}_{\text {cal }}$ & Significance \\
\hline Observed & 375 & 184.4 & 1.50 & 1.98 & 5.51 & Reject $\mathrm{H}_{\mathrm{o}}$ \\
\hline Expected & - & 25.0 & - & & & \\
\hline
\end{tabular}

The above table presents the results of the t-test analysis of the null hypothesis. Since the calculated t-value of 5.51 is greater than the critical t-value of 1.98, the null hypothesis is rejected and it is concluded that there is significant difference in the instructional materials used by the teachers of French and those recommended in the curriculum for teaching French.

From the results of the analysis, the following findings were made:

1. The instructional materials used by the teachers for teaching French include drawings and text books.

2. The teachers' use of instructional materials for teaching French represents $20 \%$ of the instructional materials recommended in the French language curriculum.

3. There is significant difference in the instructional materials used by the teachers of French and those recommended in the French language curriculum.

\section{DISCUSSION}

From the results, the instructional materials used by the teachers for teaching French include drawings and text books. This finding negates the view of Konomi (2015) on the importance of different types of instructional materials for teaching language, like pictures, posters, postcards, word calendars, realia, charts and so on.

It is very surprising that the teachers mostly use textbooks and drawings, probably the ones in the Government-recommended textbooks. The finding confirms the observation by Ogike (2005) that the teachers of French use conventional methods, dominated by the use of Government recommended textbooks. The finding shows that the teachers stress mechanical repetitive drills which could be 
engaged in without thought on the part of the learners (Offorma 2002). The finding also confirms the findings of Ezenwa (2007) that the teachers of French teach with the conventional methods instead of the communicative approach recommended by the national French language curriculum. This is a very big challenge to effective classroom teaching of French.

From the results, the teachers' use of instructional materials for teaching French represents $20 \%$ of the instructional materials recommended in the curriculum for teaching French. This finding shows that the teachers' use of instructional materials is not adequate. It is surprising that the teachers do not use charts and pictures for teaching French which, as observed by CESA Languages Abroad (2015), help to project real French people and language activities and so get the students interested in the language.

The teachers' non-use of authentic materials is a worrisome situation as it reveals a very big lapse in the teachers' classroom practice which, according to Offorma (2002), help the pupils to use language for real-life purposes. It negates the fact that the use of authentic materials for language teaching helps to make language learning real to the students since the students will see in them the real-life use of French.

The teachers' neglect of resources like the video, audio players and television runs contrary to the aims of CESA Languages Abroad (2015) which places some importance on audiovisual instructional materials like the television, video and film extracts in teaching the language skills. These are the school's strategies for creating an authentic and communicative environment for the students to learn language. This neglect by the teachers of French does not agree with modern pedagogical practice that places emphasis on the use Information and Communication Technology (ICT) facilities. It negates the fact that ICT resources now form part of the immediate environment of the learners in Nigeria and this environment is part of the learner characteristics that are relevant for language learning.

From the results that the teachers' use of instructional materials for teaching French represents $20 \%$ of the instructional materials recommended in the curriculum for teaching French, it is clear that there is significant difference in the instructional materials used by the teachers of French and those recommended in the curriculum for teaching French. The teachers' use of the instructional materials falls below the standard set by the Federal Ministry of Education (2012) in the French language curriculum.

This finding is a neglect of the use of a variety of instructional materials as part of the major specific skills for teaching the Language Arts. Under this situation, the teachers of French can hardly be teaching effectively. It is rather sad that the teachers still use conventional techniques, using textbooks and the drawings in them and emphasizing grammar. In so doing, as observed by Al-Masri (2005), the emphasis is still on the teachers' roles instead of the active participation of the students.

The findings of this study have some educational implications especially with regards to the teaching of French in the junior secondary schools.

1. The teachers' non-use of adequate instructional materials for teaching French will make the learning process to be abstract to the students. They can hardly be interested in learning the language.

2. The teachers' extensive use of textbooks shows that the teachers are using conventional methods in which the students read the textbooks without much interest. The expected outcomes of students acquiring and using the language skills cannot be realized.

3. Since the teachers are not using the right techniques for teaching French in the schools, the teachers are not teaching the language as effectively as expected.

\section{CONCLUSION}

The purpose of this survey was to evaluate the teachers' use of techniques for teaching French in the junior secondary schools in the Owerri Education Zone 1 of Imo State. The study focused on the extent of the teachers' use of the instructional materials recommended in the curriculum for teaching French in the junior secondary schools.

Based on the findings of this study, the following conclusions are drawn:

1. The instructional materials used by the teachers for teaching French include drawings and text books.

2. The teachers of French use of instructional materials for teaching 
French represents $20 \%$ of the instructional materials recommended in the curriculum for teaching French.

3. There is significant difference in the instructional materials used by the teachers of French and those recommended in the curriculum for teaching French.

\section{RECOMMENDATIONS}

Based on the findings of the study, the following recommendations are made:

1. In the French language classroom, the teachers need to use instructional materials recommended in the French language curriculum so that while using the materials, the students can use French and so acquire the language skills for communicating in the language.

2. There is need for the teachers of French to use the instructional materials recommended in the French language curriculum in teaching French since these instructional materials help to make the language learning to be concrete and real to the students.

3. There is need for the use of ICT resources like television, video in teaching French. The teachers can also introduce the use of computer to enhance the students' learning of French.

4. In their teaching of French, the teachers need to emphasize the students' acquisition of the language skills. This should guide their choice of the instructional materials to use.

5. To ensure adequate students' interest and participation, the teachers need to use authentic materials and real objects from the students' immediate environment. This will make the learning of French to be real to them.

\section{REFERENCES}

Abebe, T. T and Davidson, L. M., 2012. Assessing the role of visual teaching instructional materials in teaching English vocabulary. Language in India Strength for Today and Bright Hope for Tomorrow, Volume 12: 3 March 2012. Retrieved on $6^{\text {th }} \quad$ February, $2015 \quad$ from http://www.languageinindia.com/march20

12/tessemavocabulary.pdf

Al-Masri, R., 2005. The role of foreign language teacher in student centered classroom. Retrieved on $14^{\text {th }}$ May, 2010 from http://www.info@zajel.org

CESA Languages Abroad., 2015. Methodology. Retrieved on $6^{\text {th }}$ February, February, 2015 from http://www.cesalanguages.com/learnfrench-in-france/paris-two/languagecourses/methodology

Ezenwa, P. C. N., 2007a. Teachers' implementation of the French curriculum in Nigerian secondary schools. In B. G. Nworgu (ed.). Optimization of service delivery in the education sector: issues and strategies. Nsukka: University Publishers.

Federal Ministry of Education., 2012. Junior secondary education curriculum: French JSS 1-3. Abuja: Nigerian Educational Research and Development Council (NERDC)

Federal Republic of Nigeria., 2004. National policy on education. ( $4^{\text {th }}$ ed.) Abuja: NERDC

HATT., 2000. MFL-communicative approach. Retrieved October 28, 2006 from file://A:ICOMMUNICATIVE\%20APPROA CH.htm

Konomi, D. K., 2015. Using visual instructional materials in teaching Vocabulary in English as a foreign language classrooms with young Learners Retrieved on $6^{\text {th }}$ February, 2015 from http://conference.pixel-ed0003/FP/0311SERA209-FP-NPSE3.pdf

Offorma, G. C., 2002. Overview of modern foreign language $(\mathrm{mfl})$ methods and techniques. International Journal of Arts and Technology Education, 2 (1), 217 234.

Secondary Education Management Board, Owerri Zone., 2014. Owerri: Statistics Department. 
